\title{
WHITE HABITS, ANTI-RACISM, AND PHILOSOPHY AS A WAY OF LIFE
}

\author{
KenNeth Noe
}

\begin{abstract}
This paper examines Pierre Hadot's philosophy as a way of life in the context of race. I argue that a "way of life" approach to philosophy renders intelligible how antiracist confrontation of racist ideas and institutionalized white complicity is a properly philosophical way of life requiring regulated reflection on habits - particularly, habits of whiteness. I first rehearse some of Hadot's analysis of the "way of life" orientation in philosophy, in which philosophical wisdom is understood as cultivated by actions which result in the creation of wise habits. I analyze a phenomenological claim about the nature of habit implied by the "way of life" approach, namely, that habits can be both the cause and the effect of action. This point is central to the "way of life" philosophy, I claim, in that it makes possible the intelligent redirection of habits, in which wise habits are more the effect than simply the cause of action. Lastly, I illustrate the "way of life" approach in the context of anti-racism by turning to Linda Martín Alcoff's whiteness antieliminativism, which outlines a morally defensible transformation of the habits of whiteness. I argue that anti-racism provides an intelligible context for modern day forms of what Hadot calls "spiritual exercises" insofar as the "way of life" philosophy is embodied in the practice of whites seeing themselves seeing as white and seeing themselves being seen as white.
\end{abstract}

\section{INTRODUCTION}

In the philosophy of race, Charles Mills frequently laments professional philosophy's tendency to fetishize abstract theory so utterly that it becomes little more than a conceptual refinement factory operating with analyses so

Kenneth Noe is Assistant Professor of Philosophy at Harris-Stowe State University in St. Louis. His primary areas of research are continental philosophy, social and political philosophy (especially race), and the phenomenology of habit. His courses emphasize topics in social philosophy. 
granular as to risk losing touch with more pointed macro issues of normative social life in concreto (Mills 1998, 2005, 2014a). In a New York Times interview with George Yancy, Mills draws attention to this disciplinary trend in the context of post-Rawlsian social and political philosophy, observing in summary fashion that "Rawls himself said in the opening pages of $A$ Theory of Justice that we had to start with ideal theory because it was necessary for properly doing the really important thing: non-ideal theory, including the 'pressing and urgent matter' of remedying injustice. But what was originally supposed to have been merely a tool has become the end in itself; the presumed antechamber to the real hall of debate is now its main site" (2014b). The worry is that philosophy's focus on abstract theory is not just drawing philosophical attention away from the more fluid and organic contexts of lived experience. More specifically, this cloistering of philosophy from the often fraught and messy business of actual social realities ends up promoting the kind of cultural opacity the discipline lays claim to combat - in this instance, curbing discomfort-producing analysis of the reasons as to why, despite the common refrain of post-Civil Rights racial progress, society's levers of power remain thoroughly racialized.

His point is not that we should wholesale dispense with ideal theory but that in the course of its professionalization, philosophy has become a microcosm reflecting morally problematic trends in the broader context of democratic liberalism. Ideal theory has slipped all too easily into the role of a bourgeois escapism. "Within the geography of the normative," Mills observes, "ideal theory functions as a kind of white flight. You don't want to deal with the problems of race and the legacy of white supremacy, so, metaphorically, within the discourse of justice, you retreat from any spaces worryingly close to the inner cities and move instead to the safe and comfortable white spaces, the gated moral communities, of the segregated suburbs, from which they become normatively invisible" (2014b). Ideal theory has become in part a form of ideology, which in the context of race we can define stipulatively as a network of group-specific and codependent ideas and institutions that simultaneously prescribe and purportedly justify the enforcement of morally problematic forms of differential racial privilege $(1998,2005,2014 a)$. As one racial group (consciously or otherwise) exploits another racial group by partitioning along racial lines such baseline requirements for material freedom as educational opportunities, access to housing and credit markets, legal standing, environmentally healthy spaces, and so forth - "ideology," in this sense, describes a ready-to-hand stock of psychologically habitual patterns of normative rationale necessary to maintain the privileged advantages of the dominant group. While Mills has more 
recently taken up the language of "epistemic injustice," his point remains essentially the same. In that context, ideal theory proceeds by mapping a white social and political imaginary, utilizing the language of race neutrality, which then functions to prop up via economic and legal mechanisms what is in fact a racially nonneutral white experience of a fair and just society (in Mills's coinage, the ideal "whitopia") (2018, 45).

In short, philosophy's fetishization of ideal theory obfuscates normalized mechanisms of white complicity in the not-to-be-spoken de facto racial order by abstracting from what is in fact a racially selective experience, selectively treating historically promoted white experience as a qualified candidate on which to base a purportedly representative socio-political imaginary and subsequent roadmaps for prescriptive redress. Though Mills is not without his critics (e.g., Boettcher 2009), his claim nevertheless speaks to a broader long-standing need for mainstream professional philosophy to stage an institutional intervention involving a self-critically race-conscious evaluation of unquestioned philosophical habits - habits which have limited mainstream philosophizing to mostly white interests. Indeed, lest philosophy continue to ignore its passive complicity in signaling and tacitly promoting the racial status quo, it risks dooming its relevance to increasingly diverse societies as a discipline worthy of material investment.

While Mills and others propose in a somewhat broad fashion that philosophy should redress this issue by more deliberately integrating racially charged, nonideal analyses into its intellectual and professional matrices, I would like to gesture along a complementary albeit distinctive trajectory by drawing on some philosophical lessons from French historian of philosophy Pierre Hadot, whose work traces a common theme in the ancient traditions of Western philosophy in which philosophy (philo-sophia) is taken to be less a specialized theoretical discipline than an overarching way of life. In what follows, I argue that a "way of life" approach to philosophy renders intelligible how antiracist dedication to confronting racist ideas and white complicity is a properly philosophical way of life requiring regulated reflection on habits - particularly, habits of whiteness. I first rehearse some of Pierre Hadot's analysis of the "way of life" orientation in philosophy, in which philosophical wisdom is understood as cultivated by actions which result in the creation of wise habits. I analyze a phenomenological claim about the nature of habit implied by the "way of life" approach, namely, that habits can be both the cause and the effect of action. This point is central to the "way of life" philosophy, I claim, in that it makes possible the intelligent redirection of habits, in which wise habits are more the effect than simply the cause of action. Lastly, I illustrate the "way of life" approach in the 
context of antiracism by turning to Linda Martín Alcoff's whiteness antieliminativism, which outlines a morally defensible transformation of the habits of whiteness. I argue that antiracism provides an intelligible context for modern day forms of what Hadot calls "spiritual exercises" insofar as the "way of life" philosophy is embodied in practices of white racial self-consciousness in which whites see themselves seeing as white, see others seeing them as white, and see themselves being seen as white.

\section{HABIT AND HADOT'S "WAY OF LIFE" PHILOSOPHY}

Initially, one might be skeptical of an attempt to marshal Hadot's "way of life" philosophy in the context of antiracism on the grounds that it might end up reinforcing rather than confronting dispositions of whiteness. On many occasions, Hadot's depictions of the way of life approach to philosophizing - as variably "the soul's serenity," "the simple fact of existing," "the pleasure of existing," "pleasure derived from contemplating nature," "the soul's immateriality;" "the transcendence of the soul with respect to the body," the claim to the "attitude of wonder at that which appears and occurs is the present instant," implying "the entire universe" in a single moment, "To see a World in a Grain of Sand / And a Heaven in a Wild Flower" (Hadot cites William Blake), subverting the banality of existence with a "cosmic perspective," and so on - all point toward some sort of mystical unity in the purity of the true self and the cosmic "totality of the world" (Hadot 1995, 60, 87, 88, 99, 101, 260-61). Consider, too, Hadot's claims to the effect that philosophy as a way of life provides for us to become "citizens of the world" (Philo of Alexandria, cited by Hadot), to acquire "peace of mind (ataraxia)" and "inner freedom (autarkeia)," to live "in the present moment," "letting ourselves be neither troubled by the past nor worried by the uncertainty of the future," allowing us "to accede cosmic consciousness, by making us attentive to the infinite value of each instant, and causing us to accept each moment of existence from the viewpoint of the law of the cosmos" $(85,265,268)$.

The problem here is that, generally speaking, such transcendent musing tends to slip into the more earthbound ideological service of dubious faux-spiritualist tropes, which aim neither for a transformation beyond the subject's mere immediate feelings nor a shift in one's natural tendencies to uncritically adjust to the world as it already is rather than attempt to change it. Just as corporate tech firms in Silicon Valley appropriate Buddhist meditative practices, not toward a critique of the effects of capitalism on lived experience, of course, but as a set of psychological tools for inner-directed 
self-management in the service of productivity maximization (Rao 2018)so too can self-absorbed white liberals turn to the mystery-laden esotericism of "ancient wisdoms" as a palliative to the inevitable ennui and associated existential crises resulting from white ways of life typified by suburban flight, purposive wealth accumulation, the collective shunting of risk to racially othered communities, consumerist entitlement, and the luxury of colorblind indifference. In effect, such modern day white appropriations appear on the scene in time to complement the well-documented material proliferation of anxiety-relieving drugs among the white middle- and upper-classes.

Now before I am accused of punching up what is an obvious strawman of Hadot's text, what I have tried to do above is to sketch and to warn against a tenuous version of the "way of life" philosophy as filtered through the habitually selective parameters of ordinary, unspoken white privilege, which, as the less refined raw material to professionalized philosophy's propensity to ideal theory, finds in philosophy as a way of life a reaffirmed commitment to abstract freedom, triumphant self-interest based individualism, and white normative entitlement to spaces - arguably the central ideological prescripts of white colonial conquest and modern day neoliberalist subject formation. Indeed, the more speculative moments of Hadot's readings of the ancients lend themselves to such a selectivity. Metaphysical claims about the soul's ascent to the universal One, the equation of Being with the Good, the ultimate Beauty of the totality of the cosmos, and the inward-directedness of freedom and peace of mind merge seamlessly with abstract, white philosophical pretenses of both lay and professionalized orders. As Mills argues:

White (male) philosophy's confrontation of Man and Universe, or even Person and Universe, is really predicated on taking personhood for granted and thus excludes the differential experience of those who have ceaselessly had to fight to have their personhood recognized in the first place. Without even recognizing that it is doing so, Western philosophy abstracts away from what has been the central feature of the lives of Africans transported against their will to the Americas: the denial of black humanity and the reactive, defiant assertion of it. $(1998,9)$

In the spirit of Mills's critique of philosophy as ideal theory, then, the question becomes: How can philosophy as a way of life be made relevant to marginalized groups whose daily experiences often seem to suggest little to no confirmation of the truth of the kinds of speculative philosophizing which characterize the white traditions which are most associated with it?

In what sense does the "incommensurable value of existence" have meaning for racially targeted black males, for instance, whose lives are 
beset by the Kafkaesque panoptics of white gazes and the white gaslighting of black perception so utterly that, for example, driving while black, walking while black, indeed, being while black, necessitate the kinds of demoralizing behavioral adaptations intended to mitigate what is in fact the all-too-stark possibility of life-threatening consequences stemming from white anxieties in the presence of black bodies? Consider George Yancy's phenomenology of the white gaze, which describes what he calls "the elevator effect," that is, the encounter of a black body and a white body in an enclosed space in which the black body perceives the white body perceiving the black body in the ways of whiteness: "Independently of any threatening action on my part, my Black body, my existence in Black, poses a threat. . . . It is as if my Black body has always already committed a criminal deed. . . My dark body occludes the presumption of innocence" (2017, 19-20). A case in point: in an illuminating video interview with Al Jazeera, James Badue recalls a friend who, while driving, was known to "sticky" his license and registration each on opposite sides of the steering wheel in order to prevent having to reach into the glove compartment or his pockets when pulled over by law enforcement. "That eliminates the thought process and fear that the policeman might have," Badue reasons, "so we're going based off the fear that they have" (Takruri, 2017). "Why do we have to live in an 'am I gonna live or survive' kind of state, that kind of mentality?," he continues. "Can you imagine that? You know who does that? People in a war. They live with that mentality when they're on a battlefield. Live or die. Why do I have to do that, [while] driving?" Indeed, if the "totality of [one's particular] world" includes centuries of enslavement; subproletarian labor; racially precluded access to housing, credit markets, and educational opportunities; narratives of black pathology (e.g., color-coded ascriptions of a priori criminality and white presumptions of black guilt); and the systemic downplaying and/or outright white erasure of these facts from national consciousness - how can one be expected to take philosophically seriously the notion that the mere fact of being is itself worthy of splendor, let alone entertain in any serious way the ultimate unity and rational harmony of the universe?

In truth, the deeper meaning of Hadot's way of life philosophy lies in the urgency it claims for reflecting on the deepest habits constituting the self in its relationship to its world. As such, I have found the notion of habit to be a most useful concept through which to trace how Hadot synthesizes a unified methodology across the "way of life" schools of philosophy - namely, as each starting from the premise that human beings, while (ideally) thinking beings possessed of rationality, are also (nonideally) creatures of habit subject to constitutive social influences, which unconsciously press on the mind 
and naturalize, for better or worse, received opinion, popular wisdom, widespread behaviors, and so-called common sense. Naturally, human beings do find themselves carried along through everyday life by their habits, which free up the mind to pass over mundane details and engage more complex activities requiring the deliberate, intentional focus of conscious attention. At the same time, however, humans also find themselves to be the prisoners of habit, ensnared by routine, and spiritually longing for novelty in a world that seems ever more quantified, automated, and bureaucratized.

In light of this duplicity, Claire Carlisle tracks a stark disagreement among Western philosophers concerned with whether habit is ultimately a positive or a negative force in human life $(2014,2-3)$. On the one hand, philosophers such as Descartes, Kant, and Bergson argue that habit is a source of error (Descartes), or a subverter of the autonomy required by duty (Kant), or a reducer of life to mechanical routine (the source of the comic) (Bergson). On the other hand, philosophers such as Aristotle and Hume argue that moral virtue is the offspring of habit, that through habit moral virtues are cultivated and integrated in a life that can be, on the whole, judged to be good (Aristotle), or that habit is "the great guide of human life," that which confers order and predictability on the world (Hume). For the former group, unreflective habit is impulsive and overzealous, while intentional judgment is deliberate and carefully weighed; for the latter group, habit is stable, swift, and certain, while active judgment lags behind, growing wearing in habit's wake, and unable to act having exchanged time and efficiency for an all-too-cautious due diligence. A double interpretation of habit becomes manifest, one in which habit is a deadening, unreflective force, while at the same time the very principle of embodied intelligence, the means by which we tether points of stability in a world of flux; habits are developed and sedimented, as well as loosened, unraveled, and potentially transformed in a complex, differential relationship of self and world. Accordingly, habit is both "a blessing and a curse," Carlisle suggests, akin to the Greek pharmakon - a drug that can serve as both a poison and a cure (2014, 5).

Yet, Carlisle also notes, rather in passing, that "habit can be both the source and the result of action," which points to a complex relationship of habit to the causality of thought and action $(2014,7)$. While she leaves this point unexplored in detail, its implication for grasping the significance of the way of life philosophy is profound. Consider the following: whenever one acts out of habit, the habit can be said to cause one's action; but at the same time, each time one acts out of habit the habit is thus reinforced and thereby recreated in one's action, in which case the habit can be said to be 
the effect of one's action. Whenever I say "um" out of habit, for instance, my habit of saying "um" causes me to say "um"; yet the very act of my saying "um" out of habit further entrenches my habit of saying "um," and in that way (re)creates the habit of saying "um" as the effect of the repeated act of saying "um." In this sense, habits are not strictly causal but one might say quasi-causal, in the sense that while they can come to rigidly determine one's thoughts and actions, they can also be isolated and redirected through conscious attention and deliberate effort, whereby they become the willed effect, not simply the unreflective cause, of action.

Hadot's references to the role of habit alludes to such a phenomenologically informed understanding of the self as constituted by the habits it accrues through its environmental and social interactions (1995, 135, 257, 284). "To be a philosopher," Hadot says, "implies a rupture with what the skeptics called bios, that is, daily life, when they criticized other philosophers for not observing the common conduct of life, the usual manner of seeing and acting" (57). "The philosopher lives in an intermediate state," Hadot continues, "between the domain of the habitual and the everyday, on the one hand, and, on the other, the domain of consciousness and lucidity" (103). "Philosophy, for its part, deepens and transforms habitual perception, forcing us to become aware of the very fact that we are perceiving the world, and that the world is that which we perceive" (253). In short, to do philosophy is to "create habits" (86) or "good moral habits" (101). Correspondingly, we see in Hadot's work the pursuit of wisdom itself as predicated on something like such a quasi-causal ontology of habit outlined above. Wisdom, in this sense, would thus be conceived as an activity aiming at the creation of wise habits, such that, as I am suggesting, wisdom requires habits to become more so the critically refined effect of one's actions than strictly speaking the merely accrued cause of them. To quote William James: "The great thing, then, in all education, is to make our nervous system our ally instead of our enemy. It is to fund and capitalize our acquisitions, and live at ease upon the fund. . . The more of the details of our daily life we can hand over to the effortless custody of [habit], the more our higher powers of mind will be set free for their own proper work" (1950, 122, emphases removed). For better or worse, the body accumulates habits long before a conscious mind emerges to, if ever, reflect on them. To ask after whether one's habits are merely the cause of what one thinks and does or whether they are the effect of one's deliberate inner-directed attention to oneself is to engage in a nonideal and naturalized "ethics of habit," as James calls it - an ethics which acknowledges and begins from the embodied nature of cognitive and social life, starting with the role of the nervous system and the plasticity of 
the body's neurological functioning as it takes in and calibrates information from the surrounding world, most often without one's conscious awareness.

The issue, of course, is one of self-knowledge. Most often the normalized associations of one's habitual thoughts are not easily traceable to a final, particularly discrete source but are in fact imbricated among a plurality of seemingly infinite flows of events, institutional practices, uses of language, and arrangements of socio-political authority and economic power. Indeed, human beings are not only creatures subject to the determinate causality of the physical world but are also subject to the world of thoughts and ideas. The extent of one's control over one's self and way of life by dint of reason's apparent access to an ideal imaginary of thoughts, principles, and ideas prefiguring the individual can be said to be a major unifying theme of Western philosophy, including but not limited to the ancients. Spinoza, for instance, imagines not only a continuum of anonymous and preindividual matter in the universe but also a corresponding continuum of anonymous and preindividual thought in the universe, specific conjunctions of which persons exist as modifications. William James seems to imply something similar when he argues that the Cartesian deduction of a self-grounding cogito is mistaken in that at best all we can really infer is something closer to what is meant by "it thinks" (not "I think"), in the sense of "it is raining," where the indexical "it" has no strictly specifying referent; there is no determinately existing self that is deducible from the mere event of thought's occurrence, and nothing warranted beyond the claim that thought simply goes on (1950, 225). Or consider Nietzsche's strikingly phenomenological claim that a thought comes when $i t$ wants, not when $I$ want it to $(1968,214)$. As he meditates in one of his late notebooks, "[a] thought . . comes up on me - where from? How? I simply don't know. It comes, independently of my will, usually surrounded and obscured by a mass of feelings, desires, aversions, and also other thoughts. . . J Just who does all this - I have no idea, and I am surely more a spectator than originator of this process" $(2003,34)$. As the ancients discovered long ago, persons are at least as much passive selves constituted by thought as they are, in turn, active selves freely capable of both inner examination and outwardly directed social critique.

On my view, then, the prescription to be drawn from Hadot's "way of life" philosophy consists of first turning inward to take stock of one's habitual train of mental processions whose existence, let alone provenance, are not ordinarily prima facie obvious to oneself, then subsequently turning outward to discover the external sources of one's now socio-historically contingent identity. In any case, whether, as Nietzsche suggests, persons are spectators to their own thoughts or not, the kind of social ontology required for the nonideal theorizing 
of actually functioning racial ideologies might in a similar fashion posit an ontic continuum of preindividual thought, yet here not interpreted as some sort of cosmic thought flow but as grounded in more specific socio-cultural logics. The thinking being of actually embodied persons in this sense would not be adequately captured by a theoretically transcendent viewpoint sub specie aeternitatis but instead would require necessarily immanent and nonideal phenomenological analyses of agents' socially structured embodied consciousness.

\section{INVERTING THE WHITE GAZE AS A "SPIRITUAL EXERGISE"}

Presently, such perspectives are those of racialized communities and the institutionalized habits that comprise their respective ways of life. In such contexts, however, the thinking mind and the sources of its mental furniture are in all appearances sought to be kept anonymous by operations of power invested in keeping mental activities working in the service of the predominant ideology. By dint of a manufactured anonymity, the mind's racialized associations take the form of an illusorily natural and universally distributed "common sense" $(d o x a)$; yet in truth this anonymity is not some unanalyzable self-grounding universality but in fact becomes increasingly transparent to the racially "woke" mind as it tracks the production of racist ideas in mythologically functioning racial ascriptions operating at institutional levels (through the white family, the white church, the white educational system, the white media, the white legal system, and so on). What is uncovered are processes of racialization, processes which are in effect redacted anonymously by a mostly unspoken yet de facto global pattern of socially conferred blessings and curses on the basis of color and the unchecked complicity of the system's unduly privileged beneficiaries.

James Baldwin captures the deanonymizing phenomenological distancing of whites from themselves perhaps better than anyone. In "The White Man's Guilt" he tracks the white discomfort and incoherent stammering that so often accompanies encounters of whites with the fact of their own whiteness. Such is the awkwardly familiar phenomenon of the white impromptu proliferation of psychologically defensive utterances intended to negotiate, rather than admit, the racialized truth-drawn from what could be symbolized as a white rolodex of deflective clichés anonymously filed and stored within white collective consciousness for on-the-spot reference. ${ }^{1}$ In Baldwin's words:

${ }^{1}$ Through survey and analysis of white people's responses to racially pointed questions. Eduardo Bonilla-Silva's sociological studies on race and racism can be read as tracking such implicit, and explicit, ideological commitments on behalf of whites (2017 [2003]). 
The nature of this stammering can be reduced to a plea: Do not blame me, I was not there. I did not do it. My history has nothing to do with Europe or the slave trade. Anyway, it was your chiefs who sold you to me. I was not present on the middle passage. I am not responsible for the textile mills of Manchester, or the cotton fields of Mississippi. Besides, consider how the English, too, suffered in those mills and in those awful cities! I also despise the governors of southern states and the sheriffs of southern counties, and I also want your child to have a decent education and rise as high as his capabilities will permit. I have nothing against you, nothing! What have you got against me? What do you want? (Baldwin 1998, 723-24)

Indeed, most whites know full well that racial mythologies are, philosophically speaking, bullshit. I employ this term, in a Baldwinist spirit, in the sense outlined by Harry Frankfurt in his famous essay "On Bullshit," where "bullshit," as distinct from lies, is defined as speech or action which exhibits a lack of concern for the truth $(1988,125)$. In this sense, the deanonymizing confrontation of a white person with his or her own whiteness turns out to be a philosophical test of nothing less than one's very commitment to truth and reality. Baldwin concludes: "One can measure very neatly the white American's distance from his conscience - from himself- by observing the distance between White America and Black America. One has only to ask oneself who established this distance, who is this distance designed to protect, and from what is this distance designed to offer protection?" (1998, 725). For white people, then, the propaedeutic to confronting this color-coded "image of thought" (to borrow from Gilles Deleuze) involves instituting a racially conscious self-interrogation as to the degree of one's own complicity in the socially engineered and by-design hidden (to whites) sources of one's white thoughts, feelings, attitudes, and default responses to raced perceptual stimuli. In short: making one's socialized habits of whiteness transparent to oneself.

Shannon Sullivan (2006, 2014), Terrance MacMullen (2009), Alia Al-Saji (2014), and Helen Ngo (2017) have each offered distinctive treatments of the habits of whiteness and the habits of race more generally. Drawing resources from classical American pragmatism, notably the philosophy of John Dewey, Sullivan and MacMullen expose the illusion reinforcing white anonymity that white subjectivity is discontinuous with its overtly racist past. What makes habit such a useful explanans of whiteness, according to Sullivan, is that whiteness is not something (for the most part) overtly promoted among contemporary whites but subtly signaled and absorbed via social institutions, unconsciously "seducing" white bodies to psychosomatically accrue and accept the social privileges associated with it (2006, 67). A mutually reinforcing transactional relationship thus obtains between 
white bodies and the institutions that produce them, whereby whiteness and its privileges are produced by signaling institutions and the latter are reinforced by seductive privileges unreflectively taken for granted by whites. In a similar way, MacMullen describes the white body as a "vessel" of white habits, habits which he observes are in fact destructive of white communities, producing resentment, numbness, emptiness, and a general sense of self-alienation and guilt $(2009,5,2)$. On that score it is also worth noting physician Johnathan Metzl's recent Dying of Whiteness (2019), which analyzes case studies in Missouri, Tennessee, and Kansas to show how the politics of racial resentment create contexts of "backlash governance" correlated with generally negative health outcomes in white communities, such as increasing suicides, falling life expectancies, and rising dropout rates.

Al-Saji develops what she calls "a phenomenology of hesitation" in which racialized habits are brought forth to the conscious mind in moments of interruptive bodily hesitation. She argues that affects are key to disrupting perceptual habits, since merely thinking about one's habits is not enough to change them. What is necessary, she suggests, is the creation of spaces that will bring forth the affects needed to force the body to perceive in new ways. Continuing in this vein, Ngo discusses the Unheimlichkeit ("uncanniness") of racialized embodiment. Yet while black bodies captured by white gazes live an uncanny feeling of not-being-at-home, even as "inhabitual," Ngo's analysis discloses the possibility of turning the discussion back around on white complicity, where she observes that there is a particular danger of being too much at home, "such that one stops encountering others and fails to consider what it is like to be herself in the eyes of another" (2017, 105, 108). The experience of racial alienation in the case of whites can be productive, Ngo's analysis suggests, as it creates the conditions for which whites can confront the fact of their own whiteness and begin to see themselves seeing as white and seeing themselves being seen as white, thus disrupting (or in Al-Saji's words, forcing a "hesitation" of) white habits. At a collective level, one would hope, such a deanonymizing of whites to themselves might begin to plant the seeds for a potential unity of whites and nonwhites in antiracist struggle (108).

What I am suggesting, however, is that the way of life philosophy can push further into the phenomenology of whiteness beyond an analysis of the habitual privilege of whiteness to the morally implicating complicity that such bodily and sensory habits exemplify and reinforce. ${ }^{2}$ Moreover, it might be

\footnotetext{
${ }^{2}$ On the distinction between "privilege" and "complicity" I am indebted to informal conversations with Brad Elliott Stone for his insight that the latter, not the former, better captures the morally implicating habits of whiteness.
} 
said that such a shift in whiteness discourse from the abstract acknowledgement of white privilege to the more viscerally lived discomfort of white complicity is in truth the moment at which antiracism can begin taking shape as a philosophical way of life for whites, beyond an argument/ evidence-driven acceptance of the truth in acknowledged word toward an existential embracing of the truth in practiced deed. After all, nothing motivates action like the felt reality of the potential consequences of one's own morally imbued entanglements, if only for the cruder reasons of first-person self-interest.

To the extent that one is moved by rational argument, however, it is no doubt due to its existential impact, not simply the validity of the relationship of premises to conclusion. It is here that, we should note, John Cooper's critique of Hadot's "existential" interpretation of the way of life schools is thoroughly mistaken (2012, 18-19). The former's criticism amounts to a claim against Hadot for allegedly downplaying the role of rationality and argument in the way of life schools in favor of a more fundamentally necessary "existential option" when aligning oneself with a particular set of philosophical ideas (18). "One's 'option' for any one of these philosophies in particular, far-reaching as the consequences might be for one's way of life," Cooper writes, "does not deserve to be called an 'existential' one. The only existential option involved is the basic commitment to being a philosopher, to living on the basis of philosophical reason" (19). What is so striking about this criticism is that a philosopher of such seasoned caliber would fail to understand, let alone argue otherwise, that reasons can be profoundly existential, especially as pertains to one's core sense of selfhood (as is the case with race); on the contrary, pace Cooper, I would suggest that reasons are indeed essentially so, as I see little in the way of evidence warranting the claim that anyone's habits were ever transformed through rational argument alone without it also having tapped into something of existential significance.

Yet Cooper's misgivings amount to more than a merely semantic quibble over "reason" and "existential," for, if we follow him, they affect how "spiritual exercises" are to be understood, which he describes as nonrational (20). Indeed, it is one thing to criticize and in part reject Hadot's interpretation of the ancient schools on the grounds that it imports anachronistic language of Christian spiritualism and mistakenly ascribes it to philosophy in classical antiquity, but it is quite another to conclude on those grounds that the way of life schools took philosophy to be more a cognitive and intellectual practice than "spiritual exercises" might connote. In Hadot's words, on the contrary: 
It is a concrete attitude and determinate life-style, which engages the whole of existence. The philosophical act is not situated merely on the cognitive level but on that of the self and being. It is a progress which causes us to be more fully, and makes us better. It is a conversion that turns our entire life upside down, changing the life of the person who goes through it. It raises the individual from an inauthentic condition of life, darkened by unconsciousness . . . to an authentic state of life, in which he attains self-consciousness, an exact vision of the world. (1995, 82-83)

Cooper's description of spiritual exercises as "meditation, self-exhortation, memorization, and recitation to oneself bits of sacred text, causing in oneself devoted prayerful or prayer-like states of consciousness and mystical moments" (22) is therefore a very limited understanding of what we should have in mind. Such an understanding of spiritual exercises lends itself to some sort of quasi-religious introspection - which Cooper seems to be aiming at in order to criticize as nonrational - and misses the broader point of the way of life philosophy, which, on my view, is both rational and existential: the socially grounded self-examination and active transformation of culturally accrued habits of body and mind shaped by socially injurious ideological commitments.

As such, the way of life orientation in philosophy offers resources appropriate to an antiracist ethos, an enterprise itself both rational and existential. In particular, Hadot's discussion of Bergsonian philosophy of perception in "The Sage and the World" injects into the way of life approach a sober analysis of the roles of phenomenology and art in fostering and promoting self-critical subjective comportments that would expand one's naturally selective inner awareness and outer perceptual fields (1995, 252-54). Indeed, the epistemic role of habit in the collective racialization of subjectivities is exhibited in, as Mills has it, "a consensual hallucination" whereby "white misunderstanding, misrepresentation, evasion, and self-deception" become "the most pervasive mental phenomena of the past few hundred years, a cognitive and moral economy psychically required for conquest, colonization, and enslavement," requiring "a certain schedule of structured blindness and opacities in order to establish and maintain the white polity" (1997, 18-19). Mindful reflection on the "mass of feelings, desires, aversions" of which Nietzsche speaks as clouding a clear view of the sources of one's mental habits begins with, as Bergson says, "an extension of the faculties of perceiving" (2007, 113). It is not so much that whites simply see the world differently from nonwhites but, more specifically, that whites see the world in limited and selective ways stemming from the social luxury of not having to see how race connects up with lived realities created by an 
unrelentingly adaptive history of white racist policy and silencing of dissent. The attitude of colorblindness, so culturally valorized, turns out not to be the virtue it is so often claimed. Normative racial guidelines such as "one shouldn't see color" in fact reinforce ideologically functioning perceptual blockages shaping the parameters of what whites are able to see of the world and of themselves and, consequently, end up setting limits on what whites are able to accept as the truth and the reality of the historically sedimented de facto racial order. Linda Martín Alcoff puts the problem in an appropriately blunt manner: "White children are systematically taught to become delusional" (2015, 84).

Yet interest in "whiteness" seems to be on the rise, especially in Western democracies. White people appear to be feeling the gaze of their nonwhite peers with increasing intensity, as more and more social scrutiny is levied on the historical events, policies, legal constructions, and informal backdrops of complicity by which whiteness has come to secure a synonymy with power. New concepts have emerged as scholars attempt to capture and explain the surge of white anxiety and backlash against newly emergent calls for white racial responsibility, including "white fragility," coined by Robin DiAngelo (2018) and "white rage," coined by Carol Anderson (2016) to describe the affective thrust at the center of whites' reactionary attempts to disenfranchise the black vote, weaponize identity politics in the service of establishment power, and otherwise roll back what racial progress has been made. Ibram X. Kendi's observation that racial progress actually moves along two tracks, one of antiracist progress and the other toward the adaptation and reinscription of racism, is useful here. His epic Stamped from the Beginning: The Definitive History of Racist Ideas in America demythologizes the notion of racial progress by tracking through American history the simultaneity of antiracist resistance and adaptive racist backlash. "That's not to say that antiracist reformers have not made progress in exposing and burying racist policies over the years. But racist reformers have made progress too. ... [A]s Americans have discarded old racist ideas, new racist ideas have constantly been produced for their renewed consumption" (2016, 8, 507). From slavery to emancipation, from Jim Crow to Civil Rights, from police brutality and mass incarceration to Black Lives Matter, white self-interest, Kendi observes, has proven an unrelenting galvanizer in economics, politics, legislation, education, and virtually all facets of institutional life in the United States, adaptively reproducing increasingly subtle forms of discrimination. Tacit white support through a widespread condition of what we might call "white incontinence" (akrasia) could help explain the historically persistent failure of the efforts of moral suasion. 
This has led some to advocate the wholesale eradication of whiteness in order to achieve an antiracist society. After all, it is one thing for whites to stage, at an individual level, an inner-directed analysis of their own habits of complicit whiteness but quite another to institutionalize a collective outcomes-based assault on disparity-producing public policies that embody the whiteness problem and generate the very individuals whose identity, their very existential sense of selfhood, is based on the maintenance of race-based privileges. Indeed, as psychologist Bobby Wright once claimed, "Everywhere one finds Whites and Blacks in close proximity to each other, whether it is Chicago or Zimbabwe, the Whites are in control," an "extraordinary universal phenomenon which defies every known statistical law of probability. ... [ ]n their relationship with the Black race, Europeans (Whites) are psychopaths and their behavior reflects an underlying biologically transmitted proclivity with roots deep in their evolutionary history" $(1984,2)$. "Behavioral scientists generally agree that there is no known cure for the psychopath. . . Therefore," Wright concludes, "since Blacks are at war with psychopaths, violence is the only way" (12). Does antiracism as a philosophical way of life entail the elimination of "whiteness"?

In The Future of Whiteness, Alcoff argues against what she calls an "eliminativist" tendency within discussions of whiteness, that is, the notion that since whiteness is inextricably defined by its historicity, and that its history consists of a virtually irredeemable past of exploitation, oppression, the valorization of individual self-interest, the commodification of the natural world, and entitlement to spaces on the basis of racially ascribed subordinate status, an ideal essence of whiteness can be gleaned from this seemingly inalterable tendency of white collectives toward their racial others $(2015,117)$. On the contrary, Alcoff suggests, whiteness, as a social identity, is subject to the same general structures of historical production, and thus deconstruction, which apply to all identities. Her argument rejects the "white exceptionalism" presupposed by the eliminativist - that is, "the thesis that whiteness is so qualitatively distinct from other social identities that it can never mingle or harmonize," implying "an essential and fixed meaning of whiteness" predicated on a simplified historical genealogy of whiteness as de jure equivalent to white supremacy (2015, 117). Her point is that if we are to take seriously the notion that identities are socially real (that is, not biologically real nor fixed essences), then they are thus subject to potential shifts in meaning as social conditions change.

Accordingly, it is philosophically slipshod to allow presumptions of the fixed nature of whiteness to slip into the analysis and hence conclude that whiteness operates somehow independently of the de facto shifting material 
conditions of identity production (such as religious persecutions, famines, economic exploitation, and other historical and ongoing events). Of course, this is not to enlist dubious arguments to the effect that "whites were enslaved too," or other sorts of claims which assert a false equivalency of whites with groups oppressed by white majorities. What a transformation of whiteness does entail, according to Alcoff, is the initial production of "white double consciousness," which as the white correlate of W. E. B. DuBois's famous analysis from The Souls of Black Folk (2018, 7), captures the would be lived experience of whites' existentially conflicted and/or outright contradictory sense of self upon recognizing the truth of their complicity in the white racist past of which they and their previous generations have been the historical beneficiaries (Alcoff 2015, 128).

In a key chapter, entitled "Spiritual Exercises," Hadot raises the question of how it is possible to practice spiritual exercises in meaningful ways today, given the radically different contexts which distinguish modernity from its past $(1995,108)$. While he does not provide much in the way of a detailed answer, what I am suggesting, in a new direction, is that the inner-focused practice of white self-examination is one form that contemporary "spiritual exercises" finds an intelligible context, specifically regarding the necessary steps toward an openness to racial discomfort that such a project entails. Phenomenologically, this will involve seeing the world in a new way-or perhaps better, seeing the world for the first time with eyes now racially attuned. "If Seneca speaks of stupefaction," Hadot writes, "it is because he sometimes finds that he discovers the world all of a sudden. . . . At such moments, he becomes conscious of the transformation taking place in his perception of the world. Normally, he had not been in the habit of seeing the world, and consequently was not astonished by it. Now, all of a sudden, he is stupefied, because he sees the world with new eyes" (1995, 257). In the context of racial self-consciousness, these words take on a new meaning - no longer the discovery of how small and insignificant one is in the grand scheme of the infinite cosmos, for instance, but the existentially uncomfortable and morally implicating discovery of how through the very fact of one's white racial assignment - what we might call, in the spirit of Heidegger's Dasein, one's "racial thrownness" - one has accrued social advantages complicit in white supremacist systems.

While admittedly stretching the letter of Hadot's "spiritual exercises," it is nevertheless clear enough that such inner examination of white consciousness is congruent with the spirit of the way of life philosophy, insofar as it applies the practice of perceptual expansion to white consciousness, privilege, and complicity, thus creating a productive alienation of whiteness 
from itself and from the cultural forces which enable whiteness's manufactured naturalization and anonymity. In this sense, the white gaze is thus inverted, turned inward, and utilized in the antiracist service of racial self-consciousness: whites seeing themselves seeing as white, seeing others see them as white, and seeing themselves being seen as white.

\section{ANTIRACISM AND THE GOURAGE OF TRUTH}

Accordingly, philosophy as a way of life becomes a commitment to truth for truth's sake, where antiracist truth is iterated, in the language of Hadot, as a "spiritual" act of courage by nonwhites and whites alike against the forces of culturally sedimented racist habits and institutionalized white complicity. Philosophy cannot go it alone, of course; public policy is needed in concert with cultural interventions, including honest deep-diving studies of the white family, white religious organizations, and white educational institutions, the racial wealth gap, and so forth. House bill H.R. 40, which seeks to publicly fund a study of the legacy of slavery and possibilities for reparation, as well as Mehrsa Baradaran's recently proposed Homestead Act for the 21st Century are steps in the right direction.

Given white reactionism, however, white and nonwhite antiracists must continue to demonstrate courage. Yet, on the other side of the color line, such self-reflective exercises in the context of antiracism are nothing newthough here whiteness is confronted externally, and the way of life philosophy takes the form of self-preparation in the event of white backlash. Nowhere is this clearer than in the context of the American Civil Rights movement, in which philosophy as a way of life finds exemplary analysis, famously, in Martin Luther King Jr.'s 1963 'Letter from a Birmingham City Jail" (1991). There, King outlines the steps necessary for the nonviolent confrontation of racial injustice, which includes a phase of "self-purification" in preparation for what is to come when negotiation is refused. James Lawson's 1959 nonviolence workshops, inspired by Mohandas Gandhi's philosophy of satyagraha ("holding on to truth"), also demonstrate such antiracist philosophical spiritual exercises. Participants, as John Lewis recalls, fortified themselves for verbal and physical attack by staging "little sociodramas, taking turns playing demonstrators and antagonists ... [playing] angry bystanders, calling us niggers, cursing in our faces, pushing and shoving us to the floor"- - eventually putting to practice antiracist philosophy as a way of life by taking it to segregated lunch counters (Ackerman and Duval 2000, 315). To be sure, it is no accident that W. E. B. DuBois, Alain Locke, King, Lawson, Malcolm X, Stokely Carmichael, Huey Newton, Angela Davis, 
and others all held advanced degrees in philosophy, or at least made philosophy a significant foundation of their educations. More recently, projects such as Cornel West's "prophetic pragmatism" and Kristie Dotson's work on black feminism and epistemic violence further this long-standing continuity among African American philosophers who take philosophy to be in the service of addressing social issues. Such projects merge with the "way of life" antiracist philosophy advocated here.

Leonard Harris's conception of an "insurrectionist ethics" gives its own role to philosophy in combating systemic racism (1999, 2002, 2013). Harris departs from King and Lawson in emphasizing rebellion, insurrection, and the justified demand for violence to overthrow systems of oppression when moral suasion and/or nonviolent resistance (inevitably?) fails. On this view, thoroughly embedded systems of oppression such as institutionalized racism create oppressive contexts, the destruction of which requires insurrectionist agents possessed of contrary moral intuitions, character traits, and reasoning strategies than those commonly emphasized by dominant approaches to ethics, which tends to emphasize detached rationality, civility, restraint, compassion, humility, etc. Well-intentioned calls for civility, restraint, and patience in fact serve to suppress cries of moral outrage and existential despair. Indeed, because traditional paragons of Aristotelean virtue are often weaponized against those who of urgent necessity struggle to secure their dignity and humanity in the face of its normalized denial ("be patient, justice will one day prevail," "be less emotional and people will take you seriously"), traits such as audacity, tenacity, aggressiveness, enmity, indignation, and guile become the model for adversarial insurrectionism against silent adjustments to injustice. The point is that traditional moral frameworks that emphasize impartial rational deliberation and associated character virtues of the mean between the extremes are often counterproductive to ethical action in light of socially sanctioned yet routinely ignored degradation and the debilitating effects of normalized oppression.

Thus in the spirit of David Walker (1796-1830), John Brown (18001859), and Henry David Thoreau (1817-1862), Harris argues that in such contexts moral action requires dramatization, forceful demand, and the strategic channeling of rage. "The metaphorical reincarnation of Walkerian [i.e., insurrectionist] character traits," he suggests, "are appealing - tenacity, irreverence, aggressiveness, self-assurance, self-confidence, enmity, and passion - because they help make possible the sort of advocacy and authoritarian voices that demand liberation of the enslaved" (2002). Expanding on Harris's argument, Lee McBride extracts four general pillars, which standardize the main tenets of insurrectionist moral action: a willingness 
to defy norms and convention when they perpetuate injustice, a critical universal conception of personhood (not its mere habituated assumption), the acquisition of universal liberation in light of personhood, and the recognition of insurrectionist character traits necessary to push back (McBride 2017, 228-29).

We see a similar spirit in the work of Jane Elliott, whose "blue eyes/ brown eyes" exercise has been confronting whites with their own whiteness for over forty years. In A Collar in My Pocket (2016), Elliott reflects on her decades of experience leading groups of individuals of all ages, racial backgrounds, and genders through a social experiment that divides groups by the color of their eyes. Intentionally placing those with green or blue eyes in a subjugated group position (such eye color is more commonly associated with persons deemed phenotypically white) in relation to the other browneyed group, Elliott's experiment targets accrued habits of whiteness, to quite lively effect. ${ }^{3}$ The idea is that the experience will provide for a transformation of one's racial awareness and associated habits of mind by disclosing to participants, through their own experience, what it is like to be the recipient of arbitrarily grounded differential treatment and be the subject of gaslighting when one stands up to it. Historically, her work continues an oft-unspoken though woefully exceptional tradition of allyship from white women who take great pains to act for the veracity of racial equality - in the spirit of precursors such as Prudence Crandall (1803-1890), Margaret Crittendon (1822-?), and Mrytilla Miner (1815-1864) (see Davis 1983, 102).

While examples can be multiplied, the point is that such figures such as Walker, Brown, Thoreau, King, Malcolm X, Davis, or Elliott are not just "activists" possessed of a zealous passion for social change but philosophers in the way of life mold, demonstrating a willingness to put life and limb on the line for truth and reality. And while it is beyond the scope of the present article, placing the above instances into comparison raises the important question as to whether a way of life approach, whether that envisioned by Hadot or perhaps some other incarnation past or future, should be committed absolutely to nonviolence or whether certain contexts of institutional oppression are so deeply sedimented as to necessitate insurrectionist modalities of opposition that would justifiably take the form of organized violent resistance.

In any case, truth is not about making (white) people comfortable. Antiracism as a philosophical way of life necessitates white discomfort, not

${ }^{3}$ In 2009, Elliott's experiment was the subject of a Channel 4 documentary, in which psychologists were employed to analyze the behavior of the whites in the subjugated group. The documentary can be viewed online: https://www.youtube.com/watch? $v=6 \mathrm{MYHB}$ rJIIFU. 
merely for the sake of provoking "white guilt," but, as King says, "Like a boil that can never be cured as long as it is covered up but must be opened with all its pus-flowing ugliness to the natural medicines of air and light, injustice must likewise be exposed, with all of the tension its exposing creates, to the light of human conscience" $(1991,295)$. This will not be without considerable difficulty, yet there is historical and sociological evidence that institutional habits and the habits of individuals are co-constitutive. Consider, for instance, the antismoking campaigns of the 1990s, the resulting decline of smoking in subsequent youth, and the resulting increases on restrictions on use and taxation of tobacco, which gained traction with greater ease over time. While racism is a much more existentially penetrative issue and has proven itself relentlessly adaptive to redress, the transactional back and forth between public policy and the attitudes and beliefs of individual persons whereby each has its turn in constituting the other provides a broad outline for conceiving solutions. Thus, there is good reason to believe that whites seeing themselves as white, seeing others see them as white, and seeing themselves being seen as white can have a positive impact on public policy and state governance.

On the intellectual front, white philosophy instructors and their white students, including white philosophy majors and white graduate students, will have to make a significant effort to see the world through a glass nonwhitely, against the fetishization of ideal theory as philosophy's standard operating procedure. White philosophers must interrogate themselves as to what actually comes to mind when we say "we," "us," and "everyone" and become racially self-conscious when using such language in the context of teaching philosophy. My own work teaching philosophy at an HBCU has taught me as much, especially in the context of teaching philosophy as a way of life to students of color, so many of whose racialized experiences have taught them, as the proverb goes, that "When white people say 'Justice' they mean 'Just us." If philosophy as a way of life has anything to teach whites on the antiracist front, it is that truth requires inwardly directed racial self-examination as much as outwardly directed social critique. As Frederick Douglass's autobiographical reflections remind us, we come to know the world in part by turning inward and knowing ourselves; there's nothing more philosophically "way of life" than that.

\section{REFERENGES}

Ackerman, Peter, and Jack Duvall. 2000. A Force More Powerful: A Century of Nonviolent Conflict. New York: St. Martin's Press.

Alcoff, Linda Martín. 2015. The Future of Whiteness. Malden, MA: Polity. 
Al-Saji, Alia. 2014. "A Phenomenology of Hesitation: Interrupting Racialized Habits of Seeing." In Living Alterities: Phenomenology, Embodiment, and Race, edited by Emily S. Leepp, 133-172. Albany: State University of New York.

Anderson, Carol. 2016. White Rage: The Unspoken Truth of Our Racial Divide. New York: Bloomsbury.

Baldwin, James. 1998 (1965). "The White Man's Guilt." In Collected Essays, edited by Toni Morrison, 722-727. New York: Library of America. First printed in Ebony, August 1965.

Bergson, Henri. 2007 (1911). "The Perception of Change." In The Creative Mind: An Introduction to Metaphysics, translated by Mabelle L. Andison. Mineola: Dover Publications, Inc.

Boettcher, James. 2009. "Race, Ideology, and Ideal Theory." Metaphilosophy 40, no. 2: 237-59.

Bonilla-Silva, Eduardo. 2017 (2003). Racism Without Racists: Color-Blind Racism and the Persistence of Racial Inequality in America. Lanham, MD: Roman and Littlefield.

Carlisle, Claire. 2014. On Habit. New York: Routledge.

Cooper, John. 2012. Pursuits of Wisdom: Six Ways of Life in Ancient Philosophy from Socrates to Plotinus. Princeton, NJ: Princeton University Press.

Davis, Angela. 1983. Women, Race, and Class. New York: Vintage.

DiAngelo, Robin. 2018. White Fragility: Why It's So Hard for White People to Talk About Racism. Boston: Beacon Press.

DuBois, W. E. B. 2018 (1903). The Souls of Black Folk, edited by Ibram X. Kendi. New York: Penguin Books.

Elliott, Jane. 2016. A Collar in My Pocket: The Blue Eyes / Brown Eyes Exercise. Lexington, SC: CreateSpace Independent Publishing Platform.

Frankfurt, Harry. 1988. "On Bullshit." In The Importance of What We Care About: Philosophical Essays, 117-133. New York: Cambridge University Press.

Hadot, Pierre. 1995 (1987). Philosophy as a Way of Life: Spiritual Exercises from Socrates to Foucault, edited by Arnold I. Davidson. Malden, MA: Blackwell.

Harris, Leonard. 1999. "Honor and Insurrection or A Short Story about Why John Brown (with David Walker's Spirit) was Right and Frederick Douglass (with Benjamin Banneker's Spirit) was Wrong." In Frederick Douglass: A Critical Reader, edited by Bill Lawson and Frank Kirkland, 227-242. Malden, MA: Blackwell.

- 2002. "Insurrectionist Ethics: Advocacy, Moral Psychology, and Pragmatism." In Ethical Issues for a New Millennium, edited by John Howie, 192-210. Carbondale: Southern Illinois University Press.

- 2013. "Walker: Naturalism and Liberation." Transactions of the Charles S. Peirce Society 49, no. 1: 93-111.

James, William. 1950 (1890). Principles of Psychology, vol. 1. New York: Dover.

Kendi, Ibram X. 2016. Stamped from the Beginning: The Definitive History of Racist Ideas in America. New York: Nation Books.

King, Martin Luther. 1991. "Letter from a Birmingham City Jail." In A Testament of Hope: The Essential Writings and Speeches of Martin Luther King, Fr, 289-302. New York: Harper One.

MacMullen, Terrance. 2009. Habits of Whiteness: A Pragmatist Reconstruction. Bloomington: Indiana University Press. 
McBride, Lee. 2017. "Insurrectionist Ethics and Racism." In The Oxford Handbook of Philosophy and Race, edited by Naomi Zack, 225-234. New York: Oxford University Press.

Metzl, Johnathan. 2019. Dying of Whiteness: How the Politics of Racial Resentment is Killing America's Heartland. New York: Basic Books.

Mills, Charles. 1997. The Racial Contract. Ithaca, NY: Cornell University Press. . 1998. "Non-Cartesian Sums: Philosophy and the African-American Experience". In Blackness Visible: Essays in Philosophy and Race, 1-20. Ithaca, NY: Cornell University Press.

- 2005 (2017). "Ideal Theory as Ideology." Hypatia 20, no. 3 (Summer): 165-84. Reprinted in Black Rights/White Wrongs. New York: Oxford University Press.

- 2014a. "White Time: The Chronic Injustice of Ideal Theory." Du Bois Review 11, no. 1 (Summer): 27-42.

- 2014b. "Lost in Rawlsland." The Stone interview with George Yancy. New Tork Times, November 14, 2014. Accessed May 31, 2019. https://opinionator.blogs. nytimes.com/2014/11/16/lost-in-rawlsland/.

- 2018. "Through a Glass, Whitely: Ideal Theory as Epistemic Injustice." Proceedings and Addresses of the American Philosophical Association 92 (Fall): 43-77.

Ngo, Helen. 2017. The Habits of Racism: A Phenomenology of Racism and Racialized Embodiment. Lanham, MD: Lexington.

Nietzsche, Friedrich. 1968 (1886). "Beyond Good and Evil." In Basic Writings of Nietzsche, translated by Walter Kaufmann. New York: Modern Library.

—. 2003. Writings from the Late Notebooks, edited by Rüdiger Bittner. New York: Cambridge University Press.

Rao, Ankita. 2018. "Silicon Valley's Hypocritical Spirituality." Vice Newes, January 3, 2013. Accessed June 13, 2019. https://www.vice.com/en_us/article/yw5bdk/silic on-valleys-hypocritical-spirituality.

Sullivan, Shannon. 2006. Revealing Whiteness: The Unconscious Habits of Racial Privilege. Bloomington: Indiana University Press.

- 2014. Good White People: The Problem with Middle-Class White Anti-Racism. Albany: State University of New York Press.

Takruri, Dena. 2017. "Driving While Black." Al Jazeera Media Network. Interviews with Lakuiyia Stelly, James Badue, De Jauné Bickham, Benitez Matias, Jason Sole, and Joy Roscoe. Twitter, May 2, 2017. https://twitter.com/ajplus/status/85948 2659369533440.

Wright, Bobby. 1984 (1974). "The Psychopathic Racial Personality.” In The Psychopathic Racial Personality and Other Essays, 1-14. Chicago: Third World Press.

Yancy, George. 2017 (2008). Black Bodies, White Gazes: The Continuing Significance of Race in America. Lanham, MD: Roman and Littlefield. 